Work Papers of the Summer

Institute of Linguistics, University

of North Dakota Session

\title{
A relevance-based analysis of two multifunctional discourse particles: Indus Kohistani hum and -ãĩ
}

Beate Lubberger

SIL-UND

How does access to this work benefit you? Let us know!

Follow this and additional works at: https://commons.und.edu/sil-work-papers

Part of the Linguistics Commons

\section{Recommended Citation}

Lubberger, Beate (2012) "A relevance-based analysis of two multifunctional discourse particles: Indus Kohistani hum and -ãĩ," Work Papers of the Summer Institute of Linguistics, University of North Dakota Session: Vol. 52, Article 1.

DOI: 10.31356/silwp.vol52.01

Available at: https://commons.und.edu/sil-work-papers/vol52/iss1/1

This Article is brought to you for free and open access by UND Scholarly Commons. It has been accepted for inclusion in Work Papers of the Summer Institute of Linguistics, University of North Dakota Session by an authorized editor of UND Scholarly Commons. For more information, please contact und.commons@library.und.edu. 


\title{
A relevance-based analysis of two multifunctional discourse particles: Indus Kohistani hum and -ã̃̃
}

\author{
Beate Lubberger \\ University of North Dakota
}

\begin{abstract}
Relevance theory claims that words encode different types of meaning: concepts or procedures. Within this framework, discourse connectors are understood as encoding procedural instructions for the inferential part of utterance comprehension. This analysis allows for a unitary account of particles with seemingly diverse functions. Following Blass (1990) in her study of Sissala ma, English also and German auch, I examine the two discourse particles hum and -ã̃ of Indus Kohistani, a language spoken in Northern Pakistan. Both of them encode procedural meaning in that they exclude backwards contradiction as a possible way of utterance interpretation, but allow backwards confirmation and additive processing. This analysis applies to the full range of data and thus supports the interpretation of such particles as procedural devices indicating in which way to achieve relevance.
\end{abstract}

\section{Introduction}

In this paper, I examine the two Indus Kohistani particles hum and - $\tilde{a} \tilde{1}$, that are frequently used to indicate a relation of addition between two propositions, analogously to the use of English also in: Peter dug the garden. He also planted some roses, where also signals that Peter has done something else (namely plant some roses) in addition to digging the garden.

However, there are other uses of the two Indus Kohistani particles that clearly do not involve addition. One of these is analogous to the use of English even in: Jane left the concert early; she did not even wait for the break. Here, the relation between the two propositions is not one of addition; rather, the second proposition seems to confirm the first one, and also to indicate surprise that someone would leave so early (usually someone listening to a concert will at least wait for the break to leave).

Another non-additive use of the Indus Kohistani particles is analogous to the use of English indeed in: ... you will indeed find your husband, said to a woman who is determined to go and find her husband. Again, the second proposition is not meant to be processed as an addition to a previous proposition, but confirms what has been said or implied earlier: the husband will be found.

I will show that within the framework of Relevance Theory (Sperber \& Wilson 1995), both Indus Kohistani particles can be analyzed as signaling procedural constraints on the inferential part of utterance comprehension. Their underlying unitary function in both additive and non-additive uses is that of excluding backwards contradiction, leaving open the options of addition (the second proposition is interpreted analogously to the first proposition and adds information about the topic of the first proposition) or backwards confirmation (the second proposition confirms the first proposition without adding new information).

Indus Kohistani belongs to the Central (or Kohistani) Group of the Dardic languages, which are a part of the North-Western zone of Indo-Aryan and, at higher levels, of Indo-Iranian and Indo-European.

* This paper began as an assignment for a research course under the guidance of Regina Blass. Her own study of Sissala discourse particles was the inspiration for this topic. My thanks go to her for her input and constant support. I also want to thank Joan Baart for encouraging me and helping to get the paper published. I especially wish to thank Christoph Unger for his many helpful comments. 
This language is spoken in district Kohistan of the Khyber-Pakhtunkhwa Province (the former NorthWest Frontier Province) of Pakistan; the number of speakers was estimated to be about 200,000 in 1981 (Hallberg 1992). Geographically, the language area is located in the Western Himalayas, along the western bank of the river Indus and in several side valleys. A sociolinguistic survey was done in the late 1980s (Hallberg 1992), and a preliminary phonological and morphological analysis was published a decade later (Hallberg \& Hallberg 1999). Zoller (2005) published a dictionary of Indus Kohistani.

There are two main dialects of Indus Kohistani: the Kandia-Dubair dialect, spoken in the two longest side valleys; and the dialect spoken in settlements near the river Indus. However, each village and even each family speak their own variety of the main dialects. The data used in this paper are from the Pattan variety, Pattan being a village near the river Indus.

I have been in contact with speakers of Indus Kohistani since the year 2000, first in a hospital context, later while learning and analysing the language. For political and security reasons it has not been possible for me to live in the Kohistan district; my main language consultant, a female speaker, and her family, migrated to a bigger city in the region, where I can visit them.

The data used in this paper are from a large body of oral texts which I collected between 2000 and 2010. The majority of them are from my main language consultant; a few are from two other, male, mother tongue speakers. The texts have been recorded, transcribed and translated by me. They include folk stories, accounts of personal experiences, expository texts and procedural texts, sometimes interrupted by questions by me.

In section 2, I will give some examples of the different uses of hum and -ã̃. Section 3 will be a short introduction to Relevance Theory and to previous analyses of discourse markers within this framework. In sections 4 and 5 I will analyze the different uses of the particles hum and -ã̃. Section 6 contains a number of concluding remarks.

\section{Two adverbial particles in Indus Kohistani}

Indus Kohistani has two markers with an additive function: one of them is the independent word hum. This is originally from Persian ham. It is possible that this particle made its way into Indus Kohistani via Pashto, one of the languages of wider communication in the area. The entry of hum in the only dictionary of Indus Kohistani published so far (Zoller 2005 :414) is as follows: "hum, adv. 'too, also'. Psht. hum." The particle follows the entity being marked; this may be a noun, pronoun, noun phrase, postpositional phrase, adjective, adverb, verb, or verb phrase. It carries its own rising accent.

The other marker with an additive function is the enclitic particle $-\tilde{a} \tilde{\imath}(-\tilde{\imath}$ when following a vowel). It attaches to nouns, noun phrases, and postpositional phrases, and also to pronouns, adjectives, and adverbs, but not to verbs. The particle has no accent of its own; when the preceding word or phrase has a rising accent on the last syllable, this accent will shift to the particle. I assume that this particle is related to the Hindi-Urdu marker bhii. Schmidt $(1999: 63,215)$ describes this particle as having two functions: as a modal adverb it is an additive marker similar to English also, too, and as an inclusive emphatic particle its meaning is similar to that of English even. Both hum and -ã̃ are being used by all three of my language consultants.

Below I will give examples of the different functions of both particles. (1) and (2) show the typical additive function of hum and -ã̃ .

$$
\begin{aligned}
& \text { tu buçhoo hooluu ma hum buçhay hosayt } \\
& \text { you(sg) hungry if.become I also hungry will.become } \\
& \text { 'If you become hungry then I too will become hungry.' (The king's daughter, 34) }
\end{aligned}
$$




duu yũu tsay nihaar hoin khan tal hoin unda- $\tilde{u}$ hoin
two months much mist is mountain on is here-also is
'For two months there is a lot of mist; it is on the mountains; it is here, too.' (About
weather, 27)

Example (3) shows a coordinating conjunction where both parts of the coordination are marked by hum, conveying the meaning 'both ... and'. (4) shows a similar construction with the marker -ã̃ .

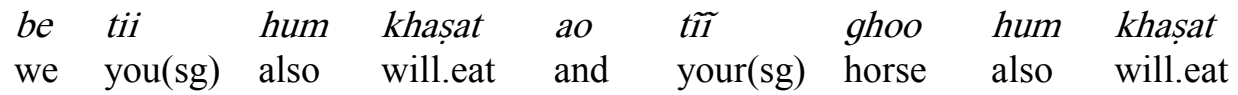

'We will eat both you and your horse.' (The king's son, 42)
tee sã̃ meě̌waala- $\tilde{I}$ rõõs
gharimaaș-ã̃ rõ̃̃s
then they
men-also
used.to.weep women-also used.to.weep
'Then both the menfolk as well as the womenfolk used to weep.' (Music, singing, dancing, 247)

The context of example (5) is a monologue about how in the past, people were poor and how little they had to eat. The speaker then goes on to say:

biin biin xalka gee lũu hum nii hõ $\tilde{u}$
few few people with salt also not used.to.be
'Some people did not even have salt.' (What people used to eat in the past, 303)

Here, the marker hum indicates that what has been mentioned earlier ('people had not much to eat') is true, and at the same time shows the scale of the lack of basic food items ('not even salt').

The marker - $\tilde{a} \tilde{\imath}$ is being used in the same way (6).

$\begin{array}{llllll}\text { kãã } & \text { xalke } & \text { gee } & \text { so- } \tilde{I} & \text { nii } & \text { hõ̃s } \\ \text { some } & \text { people } & \text { with } & \text { that-also } & \text { not } & \text { used.to.be }\end{array}$

'Some people did not even have that (that is: garlic).' (What people used to eat in the past, 49)

In the next example (7), the marker - $\tilde{a} \tilde{\imath}$ is attached to a question word.

\begin{tabular}{|c|c|c|c|c|c|}
\hline $\begin{array}{l}\text { kãã-̃ } \\
\text { who-also }\end{array}$ & $\begin{array}{l}\text { maas } \\
\text { man }\end{array}$ & $\begin{array}{l}\text { çhiçeel } \\
\text { learned }\end{array}$ & $\begin{array}{l}\text { hoon } \\
\text { is }\end{array}$ & $\begin{array}{l}\text { deeg } \\
\text { big.cooking.vessel }\end{array}$ & $\begin{array}{l}\text { ladã } 1 \\
\text { of.cooking }\end{array}$ \\
\hline $\begin{array}{l}\text { khẽ } \\
\text { then }\end{array}$ & $\begin{array}{l}S O \\
\text { that }\end{array}$ & $\begin{array}{l}\text { maas } \\
\text { man }\end{array}$ & $\begin{array}{l}\text { ladaan } \\
\text { is.cooking }\end{array}$ & & \\
\hline
\end{tabular}

'Whoever/any man who knows how to cook rice will do the cooking.' (Food, meal times, 151)

Here, $-\tilde{a} \tilde{1}$ indicates that something already suspected is indeed the case, namely that those men who know how to cook rice will cook for big functions; and it adds an element of emphasis ('any man').

In example (8), there are two instances of $-\tilde{a} \tilde{\imath}$.

\begin{tabular}{|c|c|c|c|c|c|c|c|}
\hline $\begin{array}{l}\text { biin } \\
\text { go }\end{array}$ & $\begin{array}{l}\text { khẽ } \\
\text { when }\end{array}$ & $\begin{array}{l}\text { hĩ } \\
\text { now }\end{array}$ & $\begin{array}{l}\text { yaa } \\
\text { either }\end{array}$ & $\begin{array}{l}\text { tu- } \tilde{\imath} \\
\text { you(sg)-also }\end{array}$ & $\begin{array}{l}\text { laa } \\
\text { off }\end{array}$ & $\begin{array}{l}\text { basayt } \\
\text { will.go }\end{array}$ & $\begin{array}{l}\text { yaa } \\
\text { or }\end{array}$ \\
\hline & & and-als & & $\begin{array}{l}\text { gee } \\
\text { to }\end{array}$ & & ound & \\
\hline
\end{tabular}

'If you go then either you too will get lost or you will indeed find your husband.' (Prince and fairy, 170)

The marker - $\tilde{a} \tilde{I}$ in the first clause indicates that in addition to the possibility for the addressee to get lost, someone else has already been lost; from the context it is clear that this is the husband. In the second 
clause, $-\tilde{a} \tilde{\imath}$ is not used to indicate an additive relation but rather to confirm what is already known from the context, namely the hearer's intention to find her husband.

\section{Relevance Theory}

The following brief introduction to Relevance Theory is based on Sperber and Wilson (1995), Blass (1990) and Unger (2006). Relevance Theory (RT) has been described as an 'inferential theory of communication which aims to explain how the audience infers the communicator's intended meaning' (Unger 2006). It stands in contrast to the 'code model' approach (as outlined in Blass 1990:34) whereby communication is basically seen as a matter of encoding and decoding messages. Grice (1957) went beyond the code model by noting that a communicator provides evidence (not necessarily encoded) for her intentions; the hearer on his part has to infer the intentions from the evidence. Building on this insight, Sperber and Wilson claimed that communication is largely inferential and that relevance is the single factor guiding an audience in recovering an intended message. They formulated two principles, the cognitive principle of relevance and the communicative principle of relevance:

Cognitive principle of relevance: Human cognition tends to be geared to the maximization of relevance.

Communicative principle of relevance: Every act of ostensive communication communicates the presumption of its own optimal relevance. (Sperber \& Wilson 1995:260)

In other words: Human cognition attends only to those phenomena (utterances and otherwise) that promise to be relevant in some way. In the case of communication, the single factor guiding the hearer's comprehension process is the search for relevance; the speaker, on the other hand, by the mere act of communicating verbally signals that the content of her utterance will be relevant to the hearer.

The comprehension process then goes as follows: (i) Recovery of the linguistic contents by decoding, resulting in an incomplete logical form, (ii) reference assignment, disambiguation, resolution of semantic indeterminacies such as 'big', figurative interpretation by way of inference, resulting in the fully developed propositional form or 'explicature', (iii) search for implicit contents, or 'implicatures', within a specific context, again a purely inferential process, until the search for relevance has been satisfied and thereby the speaker's intended meaning has been recovered (Wilson 2012:238). It has to be noted that although this brief description might be seen as a serial order of steps (i) to (iii), this is not the case: massive parallel processing takes place in the search for relevance.

Information which is relevant increases or improves an individual's overall knowledge of the world. We say that in this case, the hearer achieves cognitive effects. These occur in three different ways: (i) The new information, processed together with already existing assumptions leads to new conclusions or contextual implications, thus increasing the knowledge about the world, (ii) the new information confirms and strengthens already existing assumptions, and (iii) the new information contradicts already existing assumptions and, being stronger than these, will eliminate them and so improve the existing assumptions about the world. Information which does not lead to one of these three effects is not relevant to a hearer.

Search for relevance, or cognitive effects, involves costs such as processing effort and time. The human mind is geared to process only such information which promises cognitive effects with the least expenditure of time and effort. High processing costs will decrease the relevance of any input. So relevance is defined in terms of cognitive effects as well as processing costs. A hearer will therefore, when interpreting an utterance, always follow a path of least effort, access the context most accessible, and stop the interpretation process when his expectation of relevance is satisfied (Sperber and Wilson 1995).

Keeping in mind this comprehension procedure it makes sense to assume that there are linguistic devices aimed at reducing processing efforts and so optimizing relevance. Wilson and Sperber note that 
linguistic devices, that is, words, encode two basic types of information: conceptual and procedural (Wilson and Sperber 1993:1). Whereas words encoding concepts contribute to the recovery of the propositional form, others contain procedural information, aimed at constraining the inferential procedure and thereby reducing processing costs.

Blakemore (1987) was the first to analyze non-truth-conditional discourse particles (such as English so and after all) as just such devices, helping the hearer to arrive at the intended interpretation by constraining and thereby shortening the inferential process. For instance, after all indicates that the clause introduced by it contains evidence for a conclusion in a previous utterance. In this way, after all directs the hearer towards the contextual effect of strengthening an assumption. The particle so, as another example of a procedural constraint, indicates that what follows is a conclusion, thereby directing the inferential process towards the intended interpretation. These and other non-truth-conditional discourse particles encode processing constraints on the implicatures of an utterance.

There are other linguistic devices which act as constraints on other levels of the comprehension process: within Relevance Theory pronouns are analyzed as truth-conditional indexicals encoding constraints on the explicature; illocutionary and attitudinal adverbials, and hearsay particles for instance encode constraints on the higher-level explicature of an utterance (Wilson and Sperber 1993). In this paper, I will be concerned with the first-mentioned category of non-truth-conditional particles that function as constraints on the implicature.

\subsection{Non-truth-conditional discourse markers as procedural constraints: also, $\underline{\text { ma }}$, and auch}

In her analysis of the English discourse particle also, Blakemore points out that also "makes explicit a relation of addition" between two parallel clauses (Blakemore 1987:99) but at the same time interacts with focus by marking the constituent that is being added, that is, the new information. The procedural constraints encoded in also are therefore twofold: making obvious a relation of addition between two parallel clauses and putting into focus the new information, thereby guiding the hearer towards the intended additive interpretation and at the same time highlighting the pragmatically most important part of the utterance (Blakemore 1987:104).

Blass (Blass 1990), in her work on discourse particles in Sissala, a Niger-Congo, Gur language, showed that Relevance Theory can provide a unifying account for seemingly multifunctional particles such as $m a$ in Sissala, and German auch, both of which can be translated with 'also, indeed, even'. She compared them with English also and analyzed all three of them as procedural constraint particles whose basic function is that of preventing backwards contradiction (this accounts for all the functions) or preventing both backwards contradiction and backwards confirmation (in the case of additive meanings such as also). Let me present a summary of her analysis.

The examples (9) and (10) illustrate the so-called additive use.

$$
\begin{array}{ll}
\text { A: Dr. Elspeth works at Bach Hospital } \\
\text { B: Dr. Luke works at Bach Hospital }
\end{array}
$$

Looking at (9), speaker B's utterance may be understood in two ways: (a) she contradicts speaker A's utterance, saying that not Dr. Elspeth but Dr. Luke is working at Bach Hospital; (b) she is adding another person working at Bach Hospital, namely Dr. Luke. In the case of (a), the intended contextual effect would be that of contradiction and elimination of the information that 'Dr. Elspeth works at Bach Hospital', whereas in the case of (b) the relation between the two utterances would be one of addition. Blass calls the relation between the two utterances outlined in (a) 'backwards contradiction' (Blass 1990:140). The ambiguity between the two possible interpretations can be solved if speaker B uses also in her utterance to avoid interpretation (a):

(10) A: Dr. Elspeth works at Bach Hospital.

B: Dr. Luke also works at Bach Hospital. 
The function of also is just that: to exclude backwards contradiction while at the same time indicating a relation of addition between the two syntactically parallel clauses (Blakemore 1987:99, Blass 1990:138).

The next examples (11), (12), (13) show how the non-additive functions of $m a$ and auch can be accounted for within RT.

(11) A: Karen is very smart.

B: She loves to study.

Here again, there is some ambiguity: (a) the two utterances are treated as parallel clauses, in which case they stand in a relation of addition; (b) the second utterance provides evidence for the truth of the first utterance, in which case it confirms or strengthens what has been said in the first utterance. This is what Blass calls 'backwards confirmation' (Blass 1990:140). Now, to solve the ambiguity, we can add the English also to B's utterance, thereby indicating that the two clauses are parallel and are standing in a relation of addition.

(12) A: Karen is very smart.

B: She also loves to study.

Blass states that the use of also in B's utterance prevents backwards confirmation. So, also has a twofold function: to prevent backwards contradiction and to prevent backwards confirmation or, in other words, to prevent any other than parallel treatment of the two clauses.

If, on the other hand, the intended interpretation is that of (b), namely backwards confirmation, then also cannot be used whereas both Sissala $m a$ and German auch allow backwards confirmation. To achieve the backwards-confirmation effect, in English we would have to use indeed, as in (13).

(13) A: Karen is very smart.

B: Indeed she loves to study.

The two clauses are not treated as parallel; $m a$ indicates that the second proposition is a confirmation of the first one. In other words, as in all occurrences of $m a$, it prevents backwards contradiction but in this context allows backwards confirmation.

Ma, also and auch in their parallel use may achieve additional contextual effects, such as 'parallel confirmation' (Blass 1990:139), as illustrated in (14).

(14) Jane is working full-time as a nurse and is also looking after her family.

Looking at the first clause and having an assumption at hand that people who work full-time do not have much free time, the contextual implication could be that Jane has not much free time left. The second of the parallel clauses, when processed in the context of the first clause (assuming that someone who looks after her family is quite busy), will yield the same implication 'Jane does not have much free time'. So, the second clause strengthens and supports the contextual implication already derived from the first clause.

In the next example, the parallel clauses (b) and (c) are premises for the conclusion in (a).

(15) a. Yesterday I was not able to wash clothes.

b. We had no electricity for most of the day;

c. also, the water tank was nearly empty.

Here the marker also indicates, again by excluding backwards contradiction and backwards confirmation, that the second parallel clause (c) will yield the same contextual effect as the first one (b).

Another instance of parallel use of particles such as ma, auch and also is what Blass calls 'global use'. In this case, the marker indicates parallelism not between two clauses but between clusters of clauses and paragraphs of text (Blass 1990:141-3). One of her own examples from Sissala illustrates this use. 

a. 'The nim is a tree.'
b. 'It is tall ...'
c. '.... and also big.'
d. 'Its leaves are also very small.'
e. 'The nim's bark and its leaves are also very bitter without comparison.'
f. 'Birds also eat its fruit.'
g. 'Some people also clear their place and plant the nim tree.'

Blass points out that each of the clauses containing also ( $m a$ in the original Sissala example) is providing a partial answer to the question 'What is a nim tree like.' The function of also/ma is to indicate that each clause or section should be processed in parallel to the preceding clause or section, in a parallel context and with similar contextual effects. She mentions that in this function, such markers may mistakenly be interpreted as paragraph markers. However, this is just a by-product of their function as constraints on relevance (Blass 1990:142).

Examples (10), (12) and (14) to (16) have illustrated the additive use of these markers in parallel clauses. They indicate that relevance is not to be found by either backwards contradiction or backwards confirmation. Blass then goes on to analyze examples of the other uses of $m a$ and auch which cannot be translated into English with also. In such instances, ma or auch do not indicate processing of the utterance in parallel contexts and with parallel inferences to be drawn. Instead, the clause containing $m a$ or auch seems to confirm what has been mentioned in a previous utterance; thus the function is one of backwards confirmation illustrated by the following example taken from German:
A: Ich muss Kerzen kaufen für die Abende ohne Strom.
'I have to buy candles for the nights without electricity.'
B: Du solltest ein UPS-System kaufen, dann bräuchtest du keine Kerzen.
'You should purchase a UPS system; then you would not need candles.'
A: Das werde ich auch, aber bis dahin brauche ich trotzdem Kerzen.
'I will do that indeed ('also'), but up to that time I still need candles.'

A's reply containing auch is not to be treated as a clause parallel to B's utterance, nor is it in an additional relation to it. Rather, it confirms the suggestion in B's utterance: that A will indeed do as B has suggested. In this case, it is the explicature of B's utterance which is being confirmed by A's reply.

Example (18) shows a case of backwards confirmation of implicatures:
(18) A: Tim hat das Rennen gewonnen.
'Tim has won the race.'
B: Er hat ja auch jeden Tag stundenlang trainiert.

In order to arrive at the proposition being confirmed by B's utterance, we have to look at the implications of A's utterance: A must have an assumption in mind that someone who won a race must have practised a lot, which leads to the implication 'Tim has practiced a lot'. Therefore, B's reply is a backwards confirmation of an implication of A's utterance.

Besides the parallel and the backwards-confirming function there are other uses which seem not to fit into either of the two categories. One such use is in connection with question words as seen in (19), an example from German.

(19) Wohin sie auch geht, sie hat immer ein Buch dabei.

'Wherever she goes she always has a book with her.'

The English translation of the question word wohin 'where to' plus the particle auch 'also' is 'wherever'. Other examples would be 'whatever, whoever, whichever, however', so-called free relatives. In such occurrences, again, auch can be analysed as a procedural constraint in the same way, indicating 
that relevance cannot be achieved by backwards contradiction but leaving open the option of backwards confirmation.

The proposition of example (19) is expressed in (20).

(20) If she goes anywhere then she takes a book with her.

Blass notes that the function of auch in this example is 'to add emphasis, thus converting (20) to (21a) which in turn implies (21b)' (Blass 1990: 152).

(21) a. If she goes anywhere at all then she takes a book with her.

(21) b. She is never without a book.

Blass argues that auch and $m a$, in these cases, must have a procedural function as there is no truthconditional difference between propositions with and without the markers. She notes that the emphatic function of the particle must be related to the function of backwards confirmation because in both cases, something so far only suspected is being confirmed to be true as in example (16), where auch confirms the fact that 'she is indeed never without a book'. Thus, Blass suggests, the function of English free relatives with ever can be subsumed under backwards confirmation.

Another 'different' case of the use of $m a$ and auch, as mentioned above, is illustrated by (22):

Peter möchte in Berlin bleiben, auch wenn er vorübergehend arbeitslos werden sollte. 'Peter wants to stay in Berlin even ('also') if he might be unemployed for a time.'

Here, again, processing of the two propositions as parallel does not yield any relevance. That suggests that relevance might be achieved by way of backwards confirmation. And indeed, the second proposition strengthens the claim of the first proposition, that is, Peter's wish to remain in Berlin. The implicature of the second proposition might be as follows: 'Someone who is willing to be temporarily unemployed rather than leaving Berlin to find another job has a very strong wish to stay'. But besides backwards confirmation/strengthening, there is an additional effect of auch: the implication that the proposition in the scope of auch is low on a scale of desirability. In English, 'even' has to be used to express this scalar notion. So there are two elements: backwards confirmation of the wish to stay, and a scalar notion to indicate the strength of Peter's wish, the extent to which he is willing to make compromises in order to stay. Note that in these 'different' cases, a translation into English with also is not possible as also cannot be used to indicate backwards confirmation.

Blass then looks at uses of even in English and challenges the claim of Karttunen and Peters (1979, in Blass 1990:156) that scalar even only indicates, like also, some kind of parallelism and a relation of addition. She argues that scalar even is also used as backwards confirmation, as her own example (23), taken from Blass (1990:156) shows.

(23) a. Bill likes me a lot.

b. He even cleans my shoes.

As she points out, there is no need for the hearer to ask 'what else did Bill do besides cleaning my shoes?' which would be necessary for processing parallel clauses. A better interpretation for even in this example would be that it confirms the utterance in (23a) by showing the extent of Bill's liking, thus indicating backwards confirmation rather than a parallel/additional relation. Blass summarises the function of English even as being twofold: it can be used to indicate parallel processing but also to indicate backwards confirmation.

In summary, Blass states that the unifying function of all the meanings of ma, auch and English also ('also, indeed, even') is the ruling out of backwards contradiction. English also rules out both backwards contradiction and backwards confirmation whereas $m a$ and auch exclude only backwards contradiction and permit backwards confirmation. The difference between the two is just how much they exclude. 
In the following section, I will show that the two Indus Kohistani markers hum and -ã̃ work in a similar way to $m a$ and $a u c h$, namely by preventing backwards contradiction but allowing backwards confirmation.

\section{Analysis of Indus Kohistani hum as a constraint on relevance}

In section 2 we have seen that the most typical use of Indus Kohistani hum is in additive constructions, like that of English also. However, there are also instances of non-additive uses of this Indus Kohistani marker similar to Sissala $m a$ and German auch. I claim that Blass' analysis of the Sissala/German particles carries over directly to Indus Kohistani hum: it constrains the search for relevance by excluding backwards contradiction as a possible way of interpretation.

\subsection{Additive uses of hum}

One of the functions of the marker hum, introduced in section 2, is additive. When hum is used in this function, it occurs in the second of two clauses, indicating a relation of addition and a parallelism of some kind. The following examples illustrate this function. In example (24) both utterances are to be processed against the same background, namely sewing clothes:

(24) Preceding utterance:

(We) make a pocket in the side (of a man's shirt); we say 'side pocket' to it.

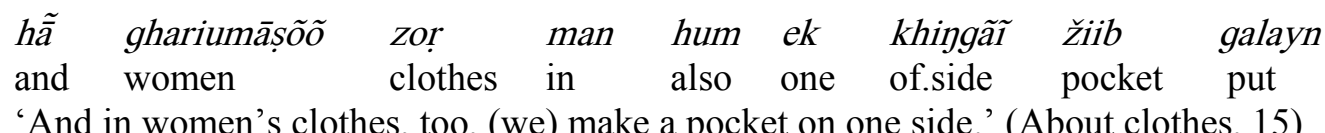

Both the preceding utterance and the utterance containing hum are to be treated as premises for the conclusion 'all Kohistani shirts have pockets'. The preceding utterance taken on its own would not necessarily have this implication; it might or might not be that women's shirts have pockets. The second utterance functions as a further premise to the conclusion 'Kohistani shirts for both men and women have side pockets'. This in turn may lead to the recovery of further implicatures such as 'Kohistani women's shirts are different from Punjabi women's shirts because they have side pockets'.

In the next example, the speaker first mentions that menfolk nowadays wear 'modern clothes' like sweaters, socks and jackets in winter; then she goes on to describe women's clothes.

(25) a. Preceding text:

In Pattan, women mostly do not wear a sweater.

They say, 'Take it off, it does not look right. We do not like it'.

b. Žaraabii hum nii șayn

socks also not wear

'They also wear no socks.' (About clothes, 108)

The contextual implication of (25a) is that women in Kohistan are much more conservative, not wanting to look 'modern' or different from other women by wearing a sweater. (25b) is strengthening this implication by adding more evidence of this attitude. So this is a case of parallel confirmation.

The next example is different. The speaker has described how a teenage boy had had epileptic seizures and was treated successfully. She then goes on:

$\begin{array}{lllll}\text { lak maasmõo tal hum yotaa een } \\ \text { small children on also } & \text { seizures } & \text { come } \\ \text { 'Small children also may suffer from seizures.' (About fits and paris, 78) }\end{array}$

There is no immediately preceding 'parallel' clause such as 'grown-up people may suffer from seizures'. The whole discussion is about fits, what causes them, etc. So this seems to be a case of global 
parallelism, where a whole paragraph or text is about one topic; and partial answers to the same question are introduced by hum. The marker signals that each one of the answers has to be processed in the same context.

The following examples show more cases of global parallelism. Indeed, this is what the particle hum is most often used for in my data.

Preceding text:

The whole text is about care of cattle. In the preceding sentences, the speaker has described the condition of a swollen udder of a cow with a calf. She then starts another paragraph with:

hãã dunõ $\tilde{o}$ hum bimaarii thi
and of.teats also illness is
'And there is also the illness of the teats...' (About cattle, 59)

The utterance introduces another subtopic of 'illnesses of cattle'. The marker hum indicates that this new topic has to be processed in the same context as, and in addition to, the previous one, and should not be interpreted as backwards contradiction.

In another text about the topic 'inheriting', several paragraphs start with a clause containing hum:

(28) In the preceding paragraph, the speaker has described one particular situation which is likely to provoke quarreling about the inheritance. Now she starts to describe another such situation:

\begin{tabular}{lllllll} 
ek & $s \tilde{u}$ & hum hoin & \multicolumn{2}{c}{ e } & ek & maas marigaa \\
one this & also happens that & one & man died
\end{tabular}

'This also happens, that a man dies ...'

$\begin{array}{llllllll}\text { hãã } & \text { ek } & \text { șee } & \text { hum } & \text { hoon } & \text { če } & \text { abaa } & \text { manaan oo puuc } \\ \text { and } & \text { one } & \text { such } & \text { also } & \text { happens that } & \text { father } & \text { says } & \text { oh son }\end{array}$

'And it happens also such that a father says to his son, 'Oh son, ...'

$\begin{array}{clll}\text { Su } & \text { hum } & \text { hõ̃s } & \text { nhaala } \\ \text { this } & \text { also } & \text { happened } & \text { look }\end{array}$

'Look, this also happened: ...' (About inheriting, 53, 94, 115)

Here again, each utterance containing hum introduces a new subsection of the topic 'quarrel about inheritance'. All of them have to be processed in the same context and add specific instances to the general topic but do not contradict it.

However, hum may also occur at the end of such a paragraph, as example (31) illustrates.

(31) The speaker has described a special kind of prayer, offered when a woman of the household is in labour. She ends this paragraph with the following words:

$\begin{array}{lll}\text { Șas hum } & \text { karaan } \\ \text { this also do } & \text { do } \\ \text { '(We) also do this.' } & \text { (Prayer, 68) }\end{array}$

In the next paragraph, she tells what people will do when there is no progress in labour. In addition to prayer, they fire a gun near the labouring woman in the hope to startle the child and speed up the process. She again ends with the phrase:

$\begin{array}{llll}\text { sas be hum } & \text { karaan } \\ \text { this we } & \text { also } & \text { do } \\ \text { 'We also do this.' (Prayer, 83) } & \end{array}$


At the end of a paragraph, hum in this function cannot indicate that the subsequent utterances are to be processed parallel to the preceding text. As this paragraph is an additional specific instance of 'problems and treatments during labour', hum clearly indicates additive use. It is just the placement of hum that is rather untypical. This example being part of an oral text, I conclude that the speaker wants to remind the hearer that this subtopic is a specific instance of the overall topic mentioned above, which has to be processed in the same context and as an addition to it.

The next examples illustrate another use of hum in a coordinated construction: Both corresponding constituents in the parallel clauses are followed by hum which has a slightly different effect. It is not only the case that one proposition has to be processed in addition to another, previous one, but that both propositions have to be processed together as one unit to arrive at the intended meaning.

$\begin{array}{lllllllll}\text { paatuu } & \text { hum } & \text { say } & \text { karayn } & \text { hãa } & \text { muuthuu } & \text { hum mand diin } \\ \text { backward } & \text { also } & \text { look } & \text { do } & \text { and } & \text { forward } & \text { also } & \text { race } & \text { give }\end{array}$

'(I) was looking backward as well as running forward.' (The earthquake, 40)

Here, the intended meaning is not so much 'I was looking backward and I was also running forward' but more like 'I was doing both, looking backward and running forward, at the same time.' Again, this clearly falls under additive use: both propositions have to be processed together, in addition to one another, in order to arrive at the intended meaning.

Examples (34) and (35) are further illustrations of this use of hum.

$\begin{array}{llllllllll}\text { alahapaak } & \text { as } & \text { sugaa } & \text { hum } & \text { sandaan } & \text { hãa } & \text { as } & \text { atshak hum } & \text { sandaan } \\ \text { God } & \text { him } & \text { beautiful } & \text { also creates } & \text { and } & \text { him } & \text { ugly } & \text { also } & \text { creates }\end{array}$

'God creates both the beautiful and the ugly child.' (The evil eye, 93)
khẽ kukõo maaril khẽ maleșe hum khagil hãã
then chicken killed when guest also ate and
tsõo hum khagil
'Then you would kill a chicken; and both the guest and you (and your family) would eat it.'
(What people used to eat in former times, 269)

In the following example, the English translation of hum in both clauses is 'neither...nor'.
asĩ abaa hum xarač
neeraan
matiãã
abaa hum
xarač
neeraan
his father also expenses not.do of.girl father also expenses not.do
'Neither his (the bridegroom's) father nor the girl's father spend (this money) for themselves.'
(Marriage in Kohistan, 33)

In these examples, the presence of the additive in both parallel clauses indicates that neither the first nor the second conjunct can be processed without the corresponding one. It is not the case that the second conjunct adds an additional premise or strengthens a conclusion drawn from the first clause; both clauses have to be processed together in order to arrive at the intended contextual effects. In (33), the implicature is that it is very dangerous indeed to run down a steep hill while looking backwards to keep away from rocks rolling down. The explicature of (35) is 'all are eating the chicken'. In a set of two parallel clauses such as (10) above, where the second clause contains an added entity and an additive marker, the hearer is being directed to interpreting the second clause as addition against the background of the first clause. In (36), where both parallel clauses are marked, not only the second clause has to be processed as addition to the first but also the first clause has to be processed as having a relationship of addition to the second clause in order to arrive at the intended meaning. So the fact that in coordinated constructions each clause is marked with hum points again to the basic function of an additive marker: making explicit a relation of addition to another parallel clause and thereby excluding backwards contradiction and backwards confirmation. 


\subsection{Non-additive uses of hum}

In the following paragraphs, I will look at examples of non-additive uses of hum. One of them can be translated with 'even'. English even has been analysed as a non-truth-conditional particle which interacts, like also, with focus and which contains a scalar element (Karttunen and Peters 1979, in Blass 1990:156). Blass has shown that in addition to its parallel use, even can also indicate backwards confirmation (Blass 1990:156-9), see also section 3.1 example (23). In Indus Kohistani, it seems that hum has both functions: parallel as well as confirmative. Example (37) illustrates the parallel use of hum when translated as 'even'. The context is a discussion about what happens when a father dies and leaves behind sons from different wives. If the father did not manage to divide the inheritance while living then his sons will start to dispute and quarrel.

(37) When a man with two wives dies ... then the oldest son will think "I will take a bit more than my share from the land, cattle, money".

Then the other brothers will say, "The father's cattle, land, money ... belongs to all of us. We won't leave you if you take more than is your share".

kal-kal șasii tal maaran hum Zhaawa pičã Ĩ mhaaliãã zhaawa
sometimes this on kill also brothers of.uncle of.mother brothers
'Sometimes they even kill (one another), the brothers and the step-brothers.' (About
inheriting, 111-14)

In the preceding utterance, the speaker states that the other brothers do not agree with their oldest brother's taking more than his share of the inheritance. One implicature of this utterance is that disagreement between brothers is likely to start a quarrel. The utterance containing hum has to be processed in parallel with this implicature. So this is an example of parallel use, but in this case, the additional effect of hum is a sense of the extremeness or unlikeliness of this specific form of quarrel, that is, killing one's brother.

The context of the following example is a discussion about divorce. The speaker has said that the first marriage is being arranged by the parents; that is: they choose a wife for their son. Then she goes on to tell what a husband will do if he is not satisfied with his parents' choice of wife:

(38) a. The husband says, "This wife is ugly; but she may stay here. I will choose another wife myself".

b. khẽ tee mut ghariũ aan
when then another wife brings
'Then (he) takes another wife.'
c. çaa gharĩ hum thi zãa watana man
three wives also are our country in
'There are even three wives (permitted) in our country.'

$\begin{array}{lllllll}\text { d. } & \text { an } & \text { tsour gharĩ } & \text { ek } & \text { xaawand gee hum thi } \\ \text { up.to four wives one husband with also are }\end{array}$
'A husband has even up to four wives.' (Divorce in Kohistan , 37-9)

Again, clauses (38b), (38c), and (38d) have to be processed in parallel; at the same time clauses (38c) and (38d) are weakly implicating the low degree of likelihood for a man to have three or four wives.

In the next example, too, hum is used to indicate an additional relation. In the preceding sentences, the speaker had described what people did not have in the past food-wise: only some people had garlic to put into a vegetable curry; bread was scarce; and they did not have any spices. She goes on: 


$\begin{array}{lllllll}\text { biin-biin } & \text { xalka } & \text { gee } & \text { lũu } & \text { hum } & \text { nii } & \text { hõ̃s } \\ \text { few } & \text { people } & \text { with } & \text { salt } & \text { also } & \text { not } & \text { used.to.be }\end{array}$

'Some people did not even have salt.' (What people used to eat in former times, 303)

Here again, (39) is to be processed in parallel with the preceding clauses; hum indicates additional evidence for the conclusion 'in the past, people were very poor' and implicates the scale of the lack of eatables.

The confirmative use of hum can be seen in the following example which is taken from a folk story about a king who is angry about his youngest daughter and wants to punish her by marrying her to the worst husband he can find. He sends his army off to find such a man, saying:
a. mut mulkõo man sand ek other countries in such one
ranzalit maas leper man
hoo
"If there is such a leprous man in other countries,
$\begin{array}{llll}\text { b. sand } & \text { ek } & \text { jariib maas hoo } \\ \text { such one poor man be }\end{array}$ if there is such a poor man,
c. če so tãã šãã hum paak neerhaa
that he his snot also clean not.can.do who is not even able to clean the snot from his nose,
d. tas darbaar man ai
him king's.court in bring
then bring him to the king's court." (The king's daughter, 16)

In this example, I do not think that clause (40c) is to be processed in parallel with and in addition to clause (40a) and (40b). The hearer does not need to access the assumption 'such a man is not able to do something else'. Instead, (40c) confirms the extent of the illness and poverty of such a man. (41) is another illustration of the confirmative use of hum:
a.
asĩ
içoos
tsay
her mother-in-law very hard
thi
b. $\tilde{u}$
tã̃ bawii
goli
she her to.daughter-in-law bread also not gives
'She does not even allow her daughter-in-law to eat properly.'
(elicited)

Here again, (41b.) is not to be treated in parallel with utterance (a). Rather, (41b.) confirms the extent of hard-heartedness by citing the worst (and most unlikely) expression of it, namely withholding food from a family member.

In my data, there are no examples of backwards confirmation using hum without this scalar element. That does not mean that such a use does not exist - only that I have not yet encountered it.

\section{3 hum and focus}

Blakemore (Blakemore 1987:98) and Blass (1990:137-8) mention that also, auch and ma interact with focus. Their syntactic position helps, together with contrastive stress, to determine what is the new information 'in focus' within an utterance. The Indus Kohistani marker hum (and - $\tilde{a} \tilde{\imath}$, see section 5) differs in so far as it always follows the constituent that is in its scope; so the syntactic position of hum alone is precise enough to indicate the entity that is in focus. hum can follow nouns, pronouns, noun 
phrases, postpositional phrases, verbs, verb phrases, adverbs and adjectives. In example (24), repeated below, the entity marked by hum is a postpositional phrase.

(24) Preceding sentence:

(We) make a pocket in the side (of a man's shirt); we say 'side pocket' to it.

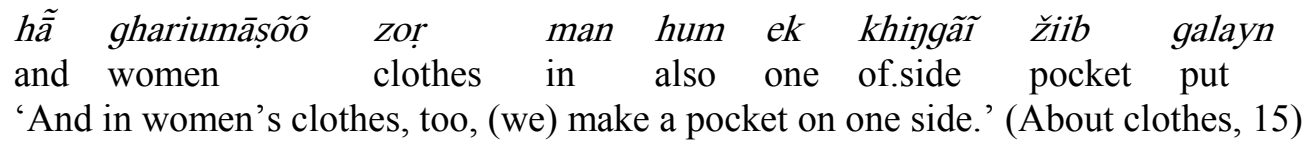

Here, hum follows the phrase 'in women's clothes', and this part of the utterance is also the new information against a background similar to that of the previous utterance. Example (27), repeated below, shows that hum is quite precise in indicating focus.

(27) Preceding text:

The whole text is about care of cattle. In the preceding sentences, the speaker has described the condition of a swollen udder of a cow with a calf. She then starts another paragraph with:

$\begin{array}{llll}\text { hãa } & \text { dunõo hum bimaarii thi } \\ \text { and of.teats } & \text { also illness is }\end{array}$

'And there is also the illness of the teats...' (About cattle, 59)

In this example, hum does not follow the NP-final noun but is placed within the NP, following one part of it i.e. the possessor of a genitive construction 'of teats'. This is the one piece of new information in this utterance, in the context of a description of different cattle illnesses.

In example (42), the marker hum follows an adverb.

(42) Preceding text: The speaker explains that in the presence of their father or older brothers, children are told to be quiet and not to speak. She then goes on that if there is a jirga (assembly of elders) ...

khẽ tala hum șu thi če lakeer maa dașat

then there also this is that young silence give

'... then there, too, the young men do not speak.' (Adab, good manners, 58)

Here again, the adverb 'there' marked by hum is also the one item of new information that is in focus.

Example (34), repeated here, shows an instance of hum following adjectives.

$\begin{array}{lllllllll}\text { alahapaak as sugaa hum sandaan hãa as atshak hum } & \text { sandaan } \\ \text { God } & \text { him beautiful also creates and him ugly also } & \text { creates } \\ \text { 'God creates both the beautiful and the ugly child.' (The evil eye, 93) }\end{array}$

hum does also follow verbs; in this case either verb or verb phrase are in its scope as is illustrated in examples (43) and (44).

(43) Preceding text: It was night; he was alone.

bhiaan hum

is.frightened also

'He was also frightened.' (Gulbagh story 1, 105)

(44) Preceding text: There is one brother in this office. He has a job there.

sabaq maniaan hum qaarii thu hãã noukrii karaan lesson cause.to.say also reciter.of.Koran is and employment does 'He also teaches reading the Koran; he is a reciter of the Koran and he is employed (in the office).' (How they found the baby, 91) 
In example (44), it is the verb phrase 'teaches reading the Koran' that is marked by hum and that is new information against the already known information of 'the brother has a job in this office'.

If a whole sentence or paragraph is in the scope of hum, a cleft construction has to be used, as example (29), repeated below, illustrates.

\begin{tabular}{|c|c|c|c|c|c|c|c|}
\hline $\begin{array}{l}\text { hãã } \\
\text { and }\end{array}$ & $\begin{array}{l}\text { ek } \\
\text { one }\end{array}$ & $\begin{array}{l}\text { see } \\
\text { such }\end{array}$ & $\begin{array}{l}\text { hum } \\
\text { also }\end{array}$ & $\begin{array}{l}\text { hoon } \\
\text { happens }\end{array}$ & $\begin{array}{ll}\check{c e} & \text { abaa } \\
\text { that } & \text { father }\end{array}$ & $\begin{array}{l}\text { manaan } \\
\text { says }\end{array}$ & $\begin{array}{l}\text { оо рuuc } \\
\text { oh son }\end{array}$ \\
\hline $\begin{array}{l}\text { sa } \\
\text { this }\end{array}$ & $\begin{array}{l}\text { kaam } \\
\text { work }\end{array}$ & $\begin{array}{l}\text { neera } \\
\text { do.not }\end{array}$ & & & & & \\
\hline
\end{tabular}

In this example, what is in the scope of hum is the constituent 'such/like this', which acts as placeholder for the subject complement 'a father says to his son ...' and all the subsequent clauses of this paragraph. In this way it is possible for hum to have complete clauses or even paragraphs in its scope.

A constituent followed by hum may be given additional focal prominence by preposing it, as the next example shows.

$$
\begin{array}{lllllll}
\text { sa } & \text { tariqa } & \text { hin } & \text { hum be } & \text { tsim dhayaan } \\
\text { this } & \text { method } & \text { with } & \text { also } & \text { we } & \text { fish catch }
\end{array}
$$

'This is another method we use to catch fish.' (Fishing, 16)

The adjunct 'also with this method' has been preposed, that is, the default ordering of S-O/Obl-V has been changed to Obl-S-O -V.

In this section I have shown that the marker hum is interacting with focus in that it helps the hearer to determine what is the new information in an utterance. The entity in the scope of hum is also the entity in focus.

\section{Analysis of Indus Kohistani-ã̃̃ as a procedural constraint}

The clitic - $\tilde{a} \tilde{I}$ (- $-\tilde{I}$ when following a vowel), as already mentioned in section 2, can attach to nouns, pronouns, noun phrases, postpositional phrases, adjectives and adverbs, but not to verbs. As -ã $\tilde{i}$ takes into its scope only the constituent it is attached to; this constituent alone is marked as 'in focus', as new information.

Like the marker hum, -ã̃ has - on first sight - several different functions. It is used in parallel clauses, in coordinated clauses, it can carry a function similar to English even, it can follow question words to form free relatives, and it can convey a confirmative meaning similar to that of English indeed. Similarly to my analysis of hum, I claim that the underlying function of the marker - $\tilde{a} \tilde{I}$ is to exclude backwards contradiction. In the following paragraphs I will first give examples of additive uses.

\subsection{Additive uses of - $\tilde{\mathrm{a}} \mathrm{i}$}

The additive use of -ã̃ is quite similar to that of hum. The following examples illustrate this parallel use:

(46) In the preceding text, the speaker has talked about how hard it is for both daughter and mother when the daughter leaves her parents' house. However, she continues ...

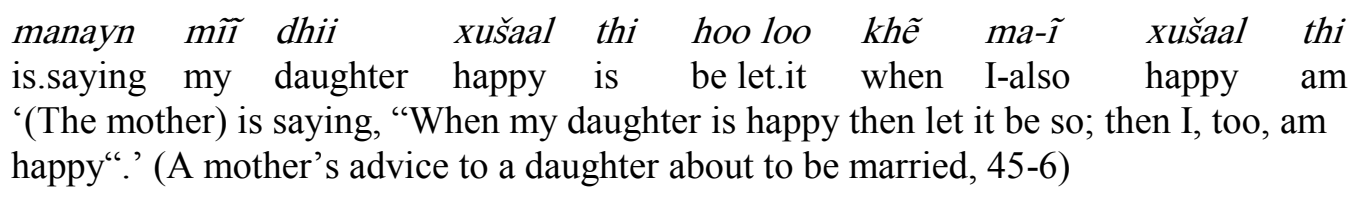


In (47), the speaker talks about the fact that sometimes, for whatever reasons, a mother may nurse another woman's child. Then this child is considered a sibling to her own children, due to them having been nursed by the same mother.

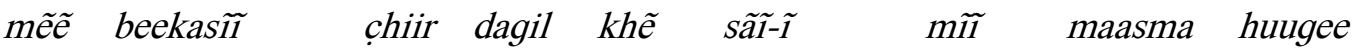

$$
\begin{aligned}
& \text { I to.someone's milk gave when they-also my children became } \\
& \text { 'When I nurse someone else's (children) then they also are considered my children.' } \\
& \text { (Family and relatives, 37) }
\end{aligned}
$$

The hearer, in order to process the clause containing the additive marker, has to supply the assumption that the children a woman nurses are usually her own. This assumption is the first conjunct which, in this case, is implicated.

The following example is from a text about how relatives of the speaker found a new-born baby-boy in a field and took him home to raise him. The speaker explains that although the baby is without a mother to nurse him, there is no lack of milk:

(48) a. There is the husband's brother's wife in the house; she is nursing. She is feeding (the foundling baby). She has a small girl in her lap (meaning: she is nursing her).

b. And down there, on the lower side (of the settlement), there are the wives of the husband's (other) brothers; they have children, look.

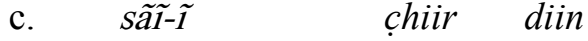
they-also milk give

'They too are feeding (the foundling baby).'

(How they found the baby, 127-131)

Clause (48a) leads to the conclusion that there is the means of feeding a motherless child. Clauses (48b) and (48c) strengthen this conclusion by providing evidence that there are at least three women who are able to nurse the baby, so there is abundance of milk.

Example (49) illustrates the use of -ã̃ in marking parallel answers to the same question 'what is considered sin?' However, as already noted for the use of hum, the additive marker is not only used at the beginning of another answer to this question ('paragraph marker', cf. Blass 1990:142) but rather when concluding the answer, before going on to the next one.

a. This is one sin: ....(description of the sin)

b. khẽ $\tilde{u}-\tilde{I} \quad$ gunaa thu nhaala

then this-also sin is look

'So this, too, is a sin, look.'

c. This is one sin:

If a woman is bad, if she does not wait on her husband, if she does not wait on her parents,

khe $\tilde{u}-\tilde{I} \quad$ gunaa thu
then this-also sin
'...so this, too, is a sin.'

d. If a person is like this: being healthy and being a Muslim he does not perform the ritual prayer...

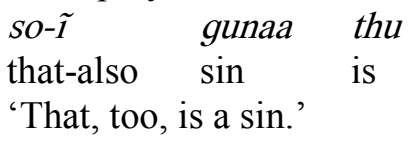


e. Preceding sentences in the same paragraph: Someone has killed another man. That man's brother now has to revenge the murder and kill someone of the murderer's family. He will do this although God hates murder. The speaker concludes this paragraph with the following sentence:

$\begin{array}{llllll}\text { khe } & \tilde{u}-\tilde{I} & \text { gunaa } & \text { thu tsoo } & \text { gunaa thu } \\ \text { then } & \text { this-also } & \text { sin } & \text { is } & \text { much } & \text { sin }\end{array}$

'Then this also is a sin; it is a big sin.' (More about sin, 54, 59, 76-7, 91)

Like hum (section 4.1), the clitic - $\tilde{a} \tilde{I}$ can be used in coordinated constructions. In the next example there are three parallel clauses, with the marker -ã̃ present in each of them.
a. maasum roon tu soiin child is.crying you hear
b. as maasmãã haq tii tal-ã̃ thu ee mii tal-ã̃ thu the of.child claim you on-also is and me on-also is
c. muyt tal-ã̃ thu
other on-also is
'If a child is crying and you hear it, then the child's claim (to be taken up and comforted) is on you as well as on me and on any other person (who hears the child crying).' (Adab, good manners, 144-6)

Again, in (50) to (52) illustrating this use, the function of the marker is not so much to indicate that the second conjunct has to be processed in a parallel context and is in a relation of addition with the first conjunct. Rather, each one of the three conjuncts marked by $-\tilde{a} \tilde{\imath}$ has to be processed in the context of the other two parallel clauses in order to arrive at the intended contextual effect. In (50), the intended meaning is that anyone nearby has the obligation to comfort a crying child. As already mentioned before, -ã̃ also marks the constituent in focus.

The background to the following example is a feud between the family of the speaker and some relatives. The speaker is going to tell about the murder of her father through men of the other feuding family and how this happened. Both parties were invited for a meal on the occasion of an engagement:

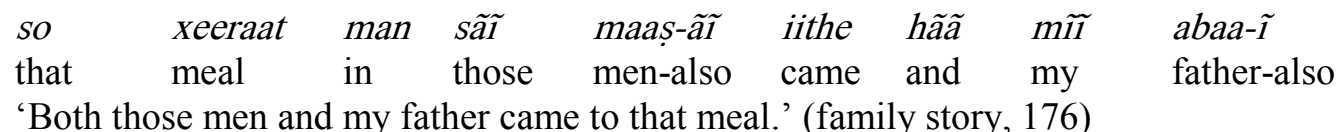

'Both those men and my father came to that meal.' (family story, 176)

The next example is from a conversation between husband and wife about money. The husband insists that his wife share her money with him, giving the following reasons:

\begin{tabular}{|c|c|c|c|c|}
\hline $\begin{array}{l}t \tilde{1}-\tilde{1} \\
\text { your-also }\end{array}$ & $\begin{array}{l}\text { maasma } \\
\text { children }\end{array}$ & $\begin{array}{l}\text { the } \\
\text { are }\end{array}$ & $\begin{array}{l}\text { mĩ- }-\tilde{1} \\
\text { my-also }\end{array}$ & $\begin{array}{l}\text { maasma } \\
\text { children }\end{array}$ \\
\hline $\mathrm{rar}$ & our children & well a & ine.' & \\
\hline $\begin{array}{l}t u-\tilde{I} \\
\text { you-also }\end{array}$ & $\begin{array}{l}\text { karayn } \\
\text { do }\end{array}$ & $\begin{array}{l}\text { ma- } \tilde{1} \\
\text { I-also }\end{array}$ & $\begin{array}{l}\text { mazduurii } \\
\text { labour }\end{array}$ & $\begin{array}{l}\text { karaan } \\
\text { do }\end{array}$ \\
\hline
\end{tabular}

'Not only you are working but I, too, am labouring.' (Who provides clothes, 192-3)

Clause (52b) has been translated with 'not only ... but also...' which again underlines the fact that both conjuncts (each of which contains two premises) have to be processed together to arrive at the intended conclusion 'we should share the expenses for our children'.

\subsection{Non-additive uses of - $\tilde{\mathrm{a}} \tilde{\mathrm{1}}$}

In section 4.2 I have already illustrated the parallel use of hum with a scalar element which can be translated as 'even'. - $\tilde{a} \tilde{\imath}$ can be used in the same way to indicate parallel confirmation, as example (53) 
shows. The background of the following utterance is the scarcity of food and spices in the past. People were happy when they were able to get some garlic, fry it and in this way add some taste to the daily vegetable dish.

(53) a. (People) used to say that spinach is very tasty when served with fried garlic.

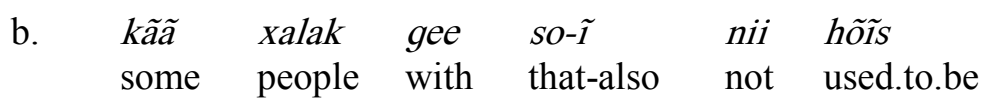

'Some people did not even have that (namely garlic).' (What people used to eat in former times, 48-9)

This utterance has to be processed in parallel to the preceding assumption 'people had no spices'; it provides additional evidence and is thus strengthening this assumption by adding the case of an 'extreme lack of spices'.

So far, the only examples of -ã̃ with this use are parallel/additive-confirmative. I suspect that there may be no backwards-confirmative use of this particle. Example (54) would be a case of backwards confirmation if the whole sentence were in the scope of the marker. However, -ã̃ takes into its scope just the element 'children' which makes the hearer ask himself 'who else does not listen to the man?' The answer to this question - the first conjunct of two parallel clauses - is implicated, 'other men do not listen to him'. Thus, the fact that -ã $\tilde{I}$ has a narrow scope (a constituent) seems to exclude the backwardsconfirmative use at least in this example.
a. $\tilde{u}$ kamzuur maas thu he weak man is 'He is a weak man.'
b. maasma- $\tilde{I}$ asĩ baal nii soaan children-also his word not listen 'Not even children listen to what he says.' (elicited)

As already mentioned in section 3.1, Blass suggests that the free-relative function of additives such as the Sissala $m a$ or the German auch is, like the other functions, a constraint on relevance, namely to process the utterance in question as backwards confirmation, adding an element of emphasis. (Blass 1990:151-2). In Indus Kohistani, we find that $-\tilde{a} \tilde{1}$ is used in the same way, as the next examples will illustrate. The speaker of (55) is talking about going to a funeral. (55) is the reply to the question 'Do you wear special clothes at a funeral?'

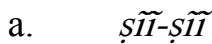
just.like.that
'(We go) just as we are.'
b. Sẫ̃ sazeel zor molgand the paak the
these worn clothes dirty are clean are
'The clothes we wear, they may be dirty; they may be clean.'
c. ghan-ã̃ the sayõ ô man been
what-also are them in go
'Whatever they are: we go wearing them.' (Visiting, 94)

Clause (55c), by emphasising the fact that the clothes may be in any condition whatsoever, confirms the implication of the previous clauses: that there are no special clothes for a funeral.

In the next example, the speaker is talking about two boys who were buried in their house by a mud slide. Miraculously, they survived:

(56) a. (They) are alive.

b. Look, these two children escaped without harm. 


\begin{tabular}{|c|c|c|c|c|}
\hline $\begin{array}{l}g i \\
\text { what }\end{array}$ & $\begin{array}{l}\text { zay } \\
\text { place }\end{array}$ & $\begin{array}{l}\text { man-ã̃ } \\
\text { in-also }\end{array}$ & $\begin{array}{l}\text { ghaal-maal } \\
\text { wounds.and.the.like }\end{array}$ & $\begin{array}{l}\text { nii } \\
\text { not }\end{array}$ \\
\hline
\end{tabular}

Again, clause (56c.), by emphasizing the unusualness of not having any scratch or wound, confirms what has been said in clause (56b.).

In the next example, it is not so obvious if apart from emphasis there is backwards confirmation as

well. Previous to the utterance, the speaker described what happens when a woman died. She particularly mentioned that a female corps has to be washed by a woman. Then she goes on to explain what to do if the deceased is a man:

\begin{tabular}{|c|c|c|c|c|c|}
\hline $\begin{array}{l}\text { meešwaal } \\
\text { man }\end{array}$ & $\begin{array}{l}\text { huugaa } \\
\text { is }\end{array}$ & $\begin{array}{l}\text { khẽ } \\
\text { when }\end{array}$ & $\begin{array}{l}\text { tee } \\
\text { then }\end{array}$ & $\begin{array}{l}k \tilde{a}-\tilde{1} \\
\text { who-also }\end{array}$ & $\begin{array}{l}\text { meešwaal } \\
\text { man }\end{array}$ \\
\hline $\begin{array}{l}\text { amã̃ } \\
\text { himself }\end{array}$ & $\begin{array}{l}\text { ween } \\
\text { from.water }\end{array}$ & $\begin{array}{l}\text { nheelasat } \\
\text { will.take.out }\end{array}$ & $\begin{array}{l}\text { kaphõo } \\
\text { shroud }\end{array}$ & $\begin{array}{ll}\tilde{o} & \text { man } \\
1 & \text { in }\end{array}$ & $\begin{array}{l}\text { dașat } \\
\text { will.give }\end{array}$ \\
\hline
\end{tabular}

I assume that in a culture where men's and women's lives are so strictly separated from one another as is the case in Kohistan, it is the underlying, not verbalized cultural assumption that corpses are never being washed by a person of the opposite sex. In this case, it goes without saying for the speaker that a male corpse is being washed by a man. The use of a free relative emphasises and confirms this fact.

The last use of -ãa is again a case of backwards confirmation; it can be translated into English with 'indeed'. In my data, I have found few occurrences. This may be due to the nature of my texts: mostly monologues and not many conversations/discussions.

The following utterance is from a folk story. A prince wants to marry and sets out to travel to his bride-to-be. On the way he has an encounter with an evil fairy that kills him and takes him away with her. The prince's bride is waiting for her husband and one day meets the fairy who had snatched him away. The bride decides to search for her husband and asks her father-in-law for permission to travel, saying:

(58) A: 'Father-in-law, I will go after my husband.

Yes, I will find my husband and bring him back.

I have got such and such information (about his whereabouts)'.

B: 'Go'.

\begin{tabular}{|c|c|c|c|c|c|c|}
\hline $\begin{array}{l}\text { biin } \\
\text { go }\end{array}$ & $\begin{array}{l}\text { khẽ } \\
\text { when }\end{array}$ & $\begin{array}{l}\text { hĩ } \\
\text { now }\end{array}$ & $\begin{array}{l}\text { yaa } \\
\text { either }\end{array}$ & $\begin{array}{l}t u-\tilde{I} \\
\text { you-also }\end{array}$ & $\begin{array}{l}\text { laa } \\
\text { off }\end{array}$ & $\begin{array}{l}\text { basayt } \\
\text { will.go }\end{array}$ \\
\hline & $\begin{array}{l}\text { tĩ̃ } \\
\text { your }\end{array}$ & & & $\begin{array}{ll}\text { tii } & g e \\
\text { you } & \text { to }\end{array}$ & & ound \\
\hline
\end{tabular}

'If you go then either you too will get lost or your husband will indeed be found'.

(Prince and Khapiri, 170)

In the first of the two clauses of B's utterance, - $\tilde{a} \tilde{I}$ indicates a parallel relation. Previously the prince had got lost; now there is the danger that in addition to that, his bride, too, may get lost. In the second clause, -ã̃ does not indicate parallel processing; it would not make sense to ask "who else will be found" as noone else was lost. Instead, relevance is achieved via backwards confirmation: the utterance confirms the previously mentioned intention to find the prince. So this would be confirmation of the explicature of A's utterance ('I will find my husband').

The following example is from a conversation with my language consultant. Previously she had told me that one of her family's two dogs had bitten a child and that they then sold one of the dogs. During a 
later visit I saw a dog on a chain and asked her if this was the dog that had bitten the child with the following words (59):

$$
\begin{aligned}
& \text { B: } \quad s \tilde{u} \quad \text { kutsur tsapaan } \tilde{a} \tilde{a} \\
& \text { this dog is.biting question particle } \\
& \text { 'Does this dog bite?' }
\end{aligned}
$$

She answered as follows (61) and at the same time told me how I should have asked (60).

$$
\begin{array}{lllll}
\mathrm{Kh}: & \multicolumn{1}{c}{\tilde{u}} & \text { kutsur-ã̃ } & \text { tsapaan } & \tilde{a} \tilde{a} \\
& \text { this } & \text { dog-also } & \text { is.biting } & \text { question particle }
\end{array}
$$

'Is this the dog that bites?'

My language consultant used the particle - $\tilde{a} \tilde{\imath}$ not only in her answer but also in the question because when I asked her I had already knowledge about one dog that had bitten someone; now I wanted to have confirmation of my suspicion that this dog was indeed the one that bites.

$$
\begin{aligned}
& \text { Kh: șu kutsur-ãa tsapaan } \\
& \text { this dog-also is.biting } \\
& \text { 'Indeed, this is the dog that bites.' }
\end{aligned}
$$

In her answer (61), the function of $-\tilde{a} \tilde{1}$ is clearly backwards confirming: what I had suspected was indeed the case. In both examples, $-\tilde{a} \tilde{\imath}$ also functions as a marker of the entity in focus.

\section{Conclusion}

The aim of this paper has been to provide a unitary account of the functions of the two Indus Kohistani markers hum and -ã̃. Within the framework of Relevance Theory, such markers are analysed as devices encoding procedural constraints; they help the hearer to arrive at the intended interpretation of an utterance in the most economical way. Based on Blass's work on discourse particles I showed that Relevance Theory offers a satisfying account of the seemingly diverse functions of hum and -ã̃. The underlying unifying function of both markers, in additive as well as in non-additive uses, is that backwards contradiction as a pathway to achieve relevance is blocked, leaving open the way for parallel/additive processing or backwards confirmation, depending on the context.

Both particles are extensively used to mark parallel relations between two clauses or constituents. One of these additive uses is the marking of coordinated constructions. The non-additive uses of hum include one that is similar to the use of English even; those of -ã̃ include one that is similar to the use of English even, another one that is similar to the use of English indeed and one that is similar to the use of English free relatives such as whoever, whatever, etc'. Both markers constrain the interpretation process in such a way that relevance can only be achieved by backwards confirmation (non-additive uses) or by processing the marked clause as standing in an additional/parallel relation to another proposition (additive uses). At the same time, both particles indicate marked focus, thereby acting as another kind of constraint by pointing out the most important part of an utterance.

How do hum and -ã̃ differ in their distribution? So far, I am not able to give a satisfactory answer. Both are in use to mark noun phrases, adjectives and adverbs of time and of location. hum however can also follow a verb and thereby mark verbs or verb phrases. My data suggest that hum can have a broader scope: verb phrases or even a whole proposition, whereas - $\tilde{a} \tilde{\imath}$ is more specific and has a narrower scope.

Taking as given that communication in all languages is inferential and is guided by the principle of relevance, Blass noted that inferential devices are expected to show similar patterns of use crosslinguistically whereas variation is to be expected in how languages correlate role to form (Blass 1990:160). The Indus Kohistani data that I have presented in this paper confirm her claim.

More data are needed to show the confirmative/non-additive use of the two Indus Kohistani particles especially in conversations. There may be other devices for indicating backwards confirmation of which I 
am not aware. Furthermore, the question whether -ãa can have a purely emphasizing function remains to be answered.

\section{References}

Blakemore, D. 1987. Semantic constraints on relevance. Oxford: Basil Blackwell.

Blass, R. 1990. Relevance relations in discourse: A study with special reference to Sissala. Cambridge: Cambridge University Press.

Grice, H. P. 1957. Meaning. Philosophical review 66: 377-88.

Hallberg, D.G. 1992. The Languages of Indus Kohistan. In O'Leary, C.F. (ed.): Sociolinguistic survey of Northern Pakistan 1: Languages of Kohistan. Islamabad: National Institute of Pakistan Studies and Summer Institute of Linguistics.

Hallberg, D.G. and C.E. Hallberg. 1999. Indus Kohistani; A preliminary phonological and morphological analysis. Islamabad: National Institute of Pakistan Studies and Summer Institute of Linguistics. (Studies in Languages of Northern Pakistan 8).

Karttunen and Peters, 1979. Conventional implicature. In Ch. Oh and D. A. Dinnen (eds): Syntax and semantics, 11: Presuppositions. New York: Academic Press.

Schmidt, R. L. 1999. Urdu: an essential grammar. London, New York: Routledge.

Sperber, D. and Wilson, D. 1995. Relevance: Communication and cognition. Second edition. Oxford: Basil Blackwell.

Unger, C. 2006. Genre, relevance and global coherence. Basingstoke: Palgrave.

Wilson, D. 2012. Metarepresentation in linguistic communication. In D. Wilson and D. Sperber (eds.): Meaning and relevance. Cambridge: Cambridge University Press.

Wilson, D. and Sperber, D. 1993. Linguistic form and relevance. Lingua 90.

Zoller, C.P. 2005. A grammar and dictionary of Indus Kohistani. Volume 1: Dictionary. Berlin, New York: Mouton de Gruyter.

Beate Lubberger

beate_lubberger@kastanet.org 